\title{
Growth dynamics of Phaeocystis antarctica- dominated plankton assemblages from the Ross Sea
}

\author{
Walker O. Smith Jr ${ }^{1, *}$, Craig A. Carlson ${ }^{2}$, Hugh W. Ducklow ${ }^{3}$, Dennis A. Hansell ${ }^{2}$ \\ ${ }^{1}$ Department of Ecology and Evolutionary Biology, University of Tennessee, Knoxville, Tennessee 37996, USA \\ ${ }^{2}$ Bermuda Biological Station, Ferry Reach, St. George's GE01, Bermuda \\ ${ }^{3}$ Virginia Institute of Marine Science, College of William and Mary, Gloucester Pt., Virginia 23062, USA
}

\begin{abstract}
Large-volume experiments were conducted using natural seawater assemblages collected in the southern Ross Sea during austral spring 1994 and summer 1995 to assess the carbon and nitrogen exchanges among phytoplankton, bacteria and dissolved organic carbon pools, and to compare the elemental partitioning in these experimental enclosures with those observed in situ. Large concentrations of particulate matter were produced in these enclosures, which were at all times dominated by the colonial haptophyte Phaeocystis antarctica. Particulate organic carbon concentrations exceeded $200 \mu \mathrm{mol} \mathrm{l}^{-1}$ at the end of the experiment. Bacterial carbon comprised only a small $(<1 \%)$ fraction of the particulate carbon, but bacteria grew at 0.15 to $0.3 \mathrm{~d}^{-1}$ and were not limited by bacteriovores. Nutrient levels decreased concomitantly with POC increases, and nitrate was reduced to undetectable levels. Dissolved organic carbon (DOC) levels remained low (less than $50 \mu \mathrm{M}$ ) while nutrients were present, but increased dramatically (to more than $200 \mu \mathrm{M}$ ) after nitrate was depleted. Growth rates calculated from changes in particulate matter concentrations were slightly below the predicted maximum based on temperature. Field studies, however, showed no depletion of nitrate, similar levels of particulate organic carbon to those found during exponential growth, low levels of DOC, and relatively low levels of bacterial biomass. It appears that $P$. antarctica in the Ross Sea does not produce large amounts of DOC during nutrient-replete growth; furthermore, because macronutrients are rarely, if ever, depleted where $P$. antarctica is dominant in the Ross Sea, it is likely that much of the carbon generated during its growth remains in the particulate pool.
\end{abstract}

KEY WORDS: Carbon - Antarctica $\cdot$ Phaeocystis $\cdot$ Phytoplankton · Bacteria $\cdot$ Dissolved organic $\cdot$ Particulate organic $\cdot$ Nitrogen

\section{INTRODUCTION}

The Ross Sea is the site of the most spatially extensive phytoplankton bloom in the entire Southern Ocean (Sullivan et al. 1993, Arrigo \& McClain 1994), and pig-

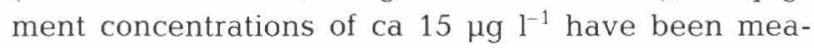
sured at the time of the biomass maximum (Smith et al. 1996). The bloom forms within the Ross Sea polynya early in the season (Smith \& Gordon 1997), and peak biomass and production are reached by mid- to late December, soon after ice completely melts and/or is advected to the north. The bloom decreases in extent

\footnotetext{
- Present address: Virginia Institute of Marine Science, College of William and Mary, Gloucester Pt., Virginia 23062, USA.E-mail: wosmith@vims.edu
}

and magnitude throughout January, and in February chlorophyll levels are approximately $1 \mathrm{\mu g} \mathrm{l}^{-1}$ or less (Arrigo \& McClain 1994, Smith et al. 1996). The processes responsible for the bloom's decline are unknown, although active grazing and sinking of colonies and/or aggregates derived from Phaeocystis have been suggested to be quantitatively important loss processes from surface waters.

The colonial haptophyte Phaeocystis antarctica always dominates the phytoplankton in the center of the polynya, although other locations in the Ross Sea (such as near the coast of Victoria Land) also support large blooms of diatoms, especially later in the season (e.g. Smith \& Nelson 1985). Particulate carbon concentrations increase by more than an order of magnitude within the Phaeocystis bloom, yet integrated stocks of 
dissolved organic carbon (DOC) levels change only slightly (Carlson et al. 1998). The limited DOC accumulation is surprising when compared to other systems. For example, Phaeocystis blooms in the North Sea generate large amounts of dissolved organic material, which ultimately result in large accumulations of emulsions which appear on European beaches after the bloom (Cadeé 1990, Lancelot et al. 1998). Phaeocystis also generates a substantial amount of extracellular polysaccharide mucus in its colonial matrix, and it has been suggested that large amounts of this material ultimately enter the DOC pool (Guillard \& Hellebust 1971, Lancelot \& Mathot 1987). Given the complex life history of Phaeocystis and the potential for unusual characteristics of its associated carbon dynamics (e.g. reutilization of the mucoid sheath in darkness to fuel respiration and the extracellular nature of the sheath; Lancelot \& Mathot 1985), it is difficult to generalize about the interactions between the particulate and dissolved pools within Phaeocystis blooms.

Previous studies have suggested that Phaeocystis had antibiotic properties as a result of the formation of acrylic acid (Sieburth 1960, Davidson \& Marchant 1992). However, studies confirming this suggestion have been difficult, as commercial acrylic acid preparations contain bactericidal compounds, and hence cannot be used in heterotrophic studies without purification. In addition, it has been found that in situ acrylic acid concentrations are too low to inhibit bacterial growth (Putt et al. 1994, Slezak et al. 1994). Recent work indicates that Phaeocystis, along with its extracellular matrix, seems to support active microbial growth which is responsible for much of the material being recycled in the upper $250 \mathrm{~m}$ of the water column (Putt et al. 1994, Brussard et al. 1996, Osinga et al. 1997). Wassmann et al. (1990) reported that as aggregates and intact colonies sank, motile unicells were released from the matrix, and the colonial matrices were then available for microbial degradation.

It is not clear what limits phytoplankton growth in the Ross Sea. Early in austral spring phytoplankton growth rates are ca $50 \%$ of the temperature-limited potential (Smith \& Gordon 1997), but these reduced rates are likely due to low photon flux densities found under the ice. During the peak biomass and production period, growth rates are equal to the temperaturelimited maximum (ca $0.5 \mathrm{~d}^{-1}$; Smith \& Gordon 1997). However, growth rates decrease markedly in January and February, and maximum light-saturated rates are only 0.1 to $0.2 \mathrm{~d}^{-1}$ (Smith et al. 1996). Trace metals potentially might limit both growth rate and yield (Martin et al. 1990). Specifically, dissolved iron concentrations are extremely low in January (less than $0.2 \mathrm{nM}$ ), and iron addition experiments stimulated growth of all species during this period (Sedwick \&
DiTullio 1997). Nitrate concentrations decrease from 30 to ca $12 \mu \mathrm{M}$ at the surface during the growing season, but only in rare, isolated locations in the Ross Sea (such as within intense, coastal diatom blooms; Smith \& Nelson 1985) are nutrients reduced to levels which are at or below detection (e.g. nitrate concentrations less than $0.1 \mu \mathrm{M})$. Although grazing is substantial at some sites, there is no evidence that grazing losses can control overall phytoplankton biomass in the Ross Sea. Hence, one of the major oceanographic paradoxes is why macronutrients are not fully utilized, both throughout the Southern Ocean and in the Ross Sea in particular, and what limits the utilization of these nutrients in situ. Trace metals are the most likely explanation for the lack of nitrate utilization (and hence phytoplankton yield), but irradiance may limit growth rates, particularly early in spring (Smith \& Gordon 1997).

Bacterial biomass and productivity in the Ross Sea are generally low, at least relative to phytoplankton. Bacterial biomass during the period of maximal phytoplankton biomass equaled only $3 \%$ of the total particulate organic matter, and bacterial productivity, while equal to that in other systems such as the North Atlantic or equatorial Pacific, was only $5 \%$ of the primary productivity (that determined on GF/F filters) (Carlson et al. 1998). Therefore the relationship between bacteria and phytoplankton (i.e. decreased importance of bacterial production in polar systems relative to phytoplankton) appears to be similar to that found in the rest of the Antarctic (Ducklow \& Carlson 1992, Karl 1993, Lochte et al. 1997). Bacterial growth rates are ca 0.1 to $0.2 \mathrm{~d}^{-1}$, but it is unknown to what degree substrate or nutrient limitation occurs in situ (Ducklow \& Carlson 1992). Carlson et al. (1998) suggested that in November and December bacteria are limited by available labile substrate; it has also been suggested that iron might limit bacterial production (Pakulski et al. 1996), but few data are available to test this hypothesis. Bacterivory is common in waters of the Antarctic (Burkill et al. 1995, Becquevort 1997), but the extent to which grazing limits bacterial standing stocks is unknown, as is the nature of the temporal coupling between bacteria and their grazers.

The objective of this study was to quantify the various transformations of carbon and nitrogen within Phaeocystis-dominated phytoplankton assemblages under controlled conditions. We hypothesized that DOC production and flux would represent an important transformation, since extensive DOC formation and turnover has been observed in other systems dominated by Phaeocystis (Lancelot et al. 1998). We further hypothesized that bacteria would respond rapidly to this input by increasing their biomass and productivity. In order to study these transformations, we conducted large-volume experiments using natural 
plankton communities (e.g. Sakshaug \& Holm-Hansen 1986, Banse 1994) and followed the concentrations and transformations within the various inorganic and organic pools through time. In parallel, we conducted a field investigation in the Ross Sea in which the same pools were assessed to compare in situ patterns with the experimental enclosures.

\section{MATERIALS AND METHODS}

Experiments and observations were conducted from the RVIB 'Nathaniel B. Palmer' in the Ross Sea, Antarctica, from November 10 to December 8, 1994 (Cruise RSP ${ }^{2}$-94) and December 17, 1995 to January 15, 1996 (Cruise $\mathrm{RSP}^{2}$-95). The study area included open waters as well as those with varying concentrations of ice. Many of the stations were sampled along $76^{\circ} 30^{\prime} \mathrm{S}$ during both cruises, and samples for experimental analysis were also collected along that transect (Fig, 1a, b). In 1994 this transect was occupied 2 times (November 13-17 and December $2-6$ ), and in 1995-96 it was sampled 3 times (December 21-29, January 5-8, and January 8-12).

Field observations. Water samples were obtained from 24 ten-liter Niskin bottles mounted on a rosette which housed a Seabird 911 conductivitytemperature-depth (CTD) system and a BioSpherical Instruments Model 240 $4 \pi$ underwater irradiance sensor. Generally, duplicate water samples were taken from depths which corresponded to $100,50,30,15,5,1$, or $0.1 \%$ of surface PFD (photon flux density), as well as from depths spaced evenly below the $0.1 \%$ isolume to $150 \mathrm{~m}$. The entire contents of 1 Niskin bottle from each depth were drained into polycarbonate carboys before subsampling for phytoplankton to ensure even distributions of particles. Subsamples for determination of ambient nutrient concentrations were taken from the carboys first, followed by those for determination of concentrations of chlorophyll a, particulate carbon and nitrogen, and phytoplankton taxonomy. The ambient concentrations of nutrients in the water samples were processed by a rapid-flow Alpkem autoanalyzer. Samples for DOC concentrations and bacterial biomass and productivity were collected directly from the duplicate Niskin bottle to minimize contamination.
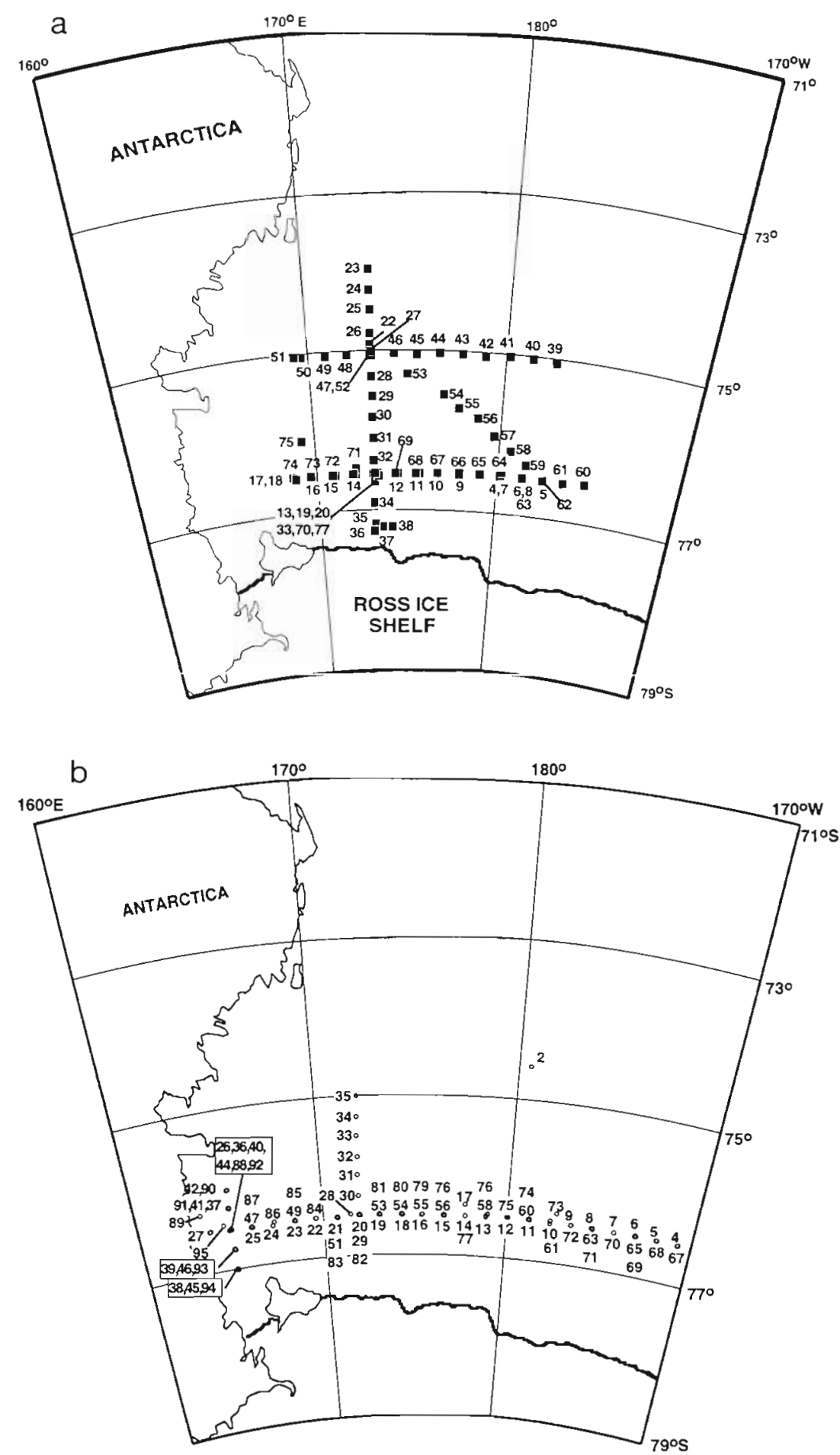

Fig. 1. Station locations and sites of experimental enclosure sampling during (a) spring 1994 and (b) summer 1995-1996 studies 
Chlorophyll a concentrations were determined fluorometrically. Small volumes $(<250 \mathrm{ml})$ were filtered through Whatman $25 \mathrm{~mm} \mathrm{GF/F}$ filters, placed in $10 \mathrm{ml}$ $90 \%$ acetone, sonicated on ice in the dark for $15 \mathrm{~min}$, extracted for an additional $15 \mathrm{~min}$, and the resultant fluorescence measured on a Turner Designs fluorometer both before and after acidification. The fluorometer was calibrated with commercially purified chlorophyll a (Sigma). Particulate organic nitrogen and carbon concentrations were assessed by filtering known volumes through $25 \mathrm{~mm}$ combusted $(2 \mathrm{~h}$ at $\left.450^{\circ} \mathrm{C}\right) \mathrm{GF} / \mathrm{F}$ filters. The filters were rinsed with small amounts (ca 5 to $10 \mathrm{ml}$ ) of $0.01 \mathrm{~N} \mathrm{HCl}$ in filtered seawater to remove inorganic carbonates, placed in combusted glass vials, capped with combusted aluminum foil, and dried at $60^{\circ} \mathrm{C}$. All samples were analyzed by high temperature pyrolysis on a Carlo-Erba Model EA-1108 elemental analyzer.

DOC samples were collected via gravity filtration through an in-line, combusted GF/F filter into a combusted glass vial. The in-line filters were attached directly to the Niskin or incubation bottle via a short piece of acid washed silicone tubing. Low vacuum filtration (<100 $\mathrm{mm} \mathrm{Hg}$ ) with combusted glass filter towers was used to collect DOC during the first enclosure experiment. The first $25 \mathrm{ml}$ were collected for analysis. Possible artifacts such as elevated DOC release could have occurred by being drawn under vacuum, and in subsequent experiments DOC was collected by in-line filtration. All DOC samples were analyzed by the high temperature combustion method using a homemade instrument as described in Carlson et al. (1998). Ultra-high-purity $\mathrm{O}_{2}$ was used as a carrier gas and flowed through the machine at $175 \mathrm{ml} \mathrm{min}^{-1}$. One hundred $\mu \mathrm{l}$ of sample were injected manually into a quartz combustion tube $(490 \times 13 \mathrm{~mm})$ packed with platinum gauze (Ionics), $7 \%$ platinum on alumina catalyst (Dymatec), Sulfix (Wako Pure Chemical Industries, Inc.) and $\mathrm{CuO}$ wire (Leeman Labs), and heated to $740^{\circ} \mathrm{C}$. Sulfix was used for the removal of halides and the $\mathrm{CuO}$ wire was used to convert $\mathrm{CO}$ to $\mathrm{CO}_{2}$. After passing through the combustion furnace, the carrier gas passed through several water traps and a copper halide trap before entering the LiCor $6252 \mathrm{CO}_{2}$ analyzer, where the signal was integrated with chromatographic software (Dynamax Macintegrator I, Version 1.3; Rainin Inst.). The resultant purified $\mathrm{CO}_{2}$ was detected with a $\mathrm{LiCor} 6252 \mathrm{CO}_{2}$ analyzer.

Extensive conditioning of the combustion tube was essential to minimize the machine blank. After conditioning, the system blank was assessed with low carbon waters (LCW) that had been referenced against blank water provided by Jonathan Sharp for the 1994 DOC intercomparison program. The system response was standardized daily with a 4 -point calibration curve of glucose solution in LCW. Deep Sargasso seawater $(>2000 \mathrm{~m})$ served as a reference standard. Analyzing LCW and deep seawater reference several times a day allowed us to assess the machine's stability from runto-run and day-to-day. Samples were acidified with $85 \% \mathrm{H}_{3} \mathrm{PO}_{4}(10 \mu \mathrm{l}$ per $10 \mathrm{ml}$ sample) and purged of inorganic carbon with $\mathrm{CO}_{2}$-free oxygen for at least 10 min immediately prior to injection.

Bacterial abundance and biovolume were determined microscopically. Samples were preserved with particle-free $25 \%$ glutaraldehyde (final concentration $1 \%$ ) and stored at $4^{\circ} \mathrm{C}$ for less then $48 \mathrm{~h}$ until slide preparation. Samples were filtered through $0.2 \mu \mathrm{m}$ black polycarbonate filters and stained with acridine orange (final concentration 0.005\%) according to Hobbie et al. (1977). Biovolumes were estimated using a Zeiss Axiophot epifluorescence microscope and a video image analysis systcm (Carlson \& Ducklow 1996). A carbon conversion factor of $120 \mathrm{fg} \mathrm{\mu m}^{-3}$ was used to convert bacterial biovolume to cellular carbon for consistency with Carlson et al. (1998). Bacterial produrtion was estimated from the incorporation of ${ }^{3} \mathrm{H}$-thymidine (TdR) using $20 \mathrm{nM}$ exogenous $\mathrm{TdR}$. In 1994 TdR incorporation assays were harvested by filtration onto $0.45 \mu \mathrm{m}$ filters, whereas in 1995 we followed the procedures of Smith \& Azam (1992). Samples were incubated at $-1.5^{\circ} \mathrm{C}$ in the dark for 3 to $12 \mathrm{~h}$ before processing. A conversion factor of $1.5 \times$ $10^{18}$ cells $\mathrm{mol}^{-1}$ of TdR was used to derive carbonbased production rates (Ducklow \& Carlson 1992).

Large-volume experiments. Large-volume experiments were conducted in acid-washed polycarbonate carboys which contained ca 25 l seawater. Results from 3 experiments (GCE94-1, GCE94-2, and GCE95-1) are reported herein. Water samples were collected either from multiple $10 \mathrm{l}$ Niskin bottles closed at the same depth (GCE94-1 and GCE94-2) or from 301 Niskin botthes (GCE95-1). Water for the 3 experiments was collected from 20, 2 and $15 \mathrm{~m}$, respectively. In addition, the water used in GCE94-2 was diluted with unfiltered deep $(200 \mathrm{~m})$ water to reduce the initial inoculum biomass. No attempt was made to sample using tracemetal clean techniques. The carboys were incubated on-deck in a deep, Plexiglas chamber through which surface seawater flowed to maintain surface seawater temperatures. Subsamples were collected throughout the experiment, although in order to minimize wall effects the remaining volume was never allowed to decrease below 101 .

Growth rates from these experiments were calculated using an exponential growth equation. Subsamples for ${ }^{14} \mathrm{C}$ incorporation into phytoplankton were collected into $280 \mathrm{ml}$ acid-washed polycarbonate bottles. All samples were inoculated with $20 \mu \mathrm{Ci}$ of $\mathrm{H}^{14} \mathrm{CO}_{3}$ and incubated for $24 \mathrm{~h}$ under the same irradiance con- 
ditions as the experimental enclosure. Samples were filtered under low vacuum through GF/F filters and placed in scintillation vials to which $0.2 \mathrm{ml} 1.0 \mathrm{~N} \mathrm{HCl}$ were added. Tests showed no significant filtration artifacts were introduced when filtration volumes and pressures were kept low. After another 24 h scintillation fluor (Ecolume, ICN) was added and the samples counted on a Beckman scintillation counter. All counts were corrected for quenching using an external standard correction.

\section{RESULTS}

\section{Large-volume experiments}

\section{GCE94-1}

The first large-volume experiment (GCE94-1) was initiated early in the 1994 cruise (seawater collected on November 14 from Stn 7 ) and followed for $19 \mathrm{~d}$. Phaeocystis antarctica dominated the phytoplankton assemblage throughout the experiment. Nitrate and phosphate declined rapidly, with the maximal rate of decrease between Days 5 and 9 (Fig. 2a). Nitrate declined to less than $0.5 \mu \mathrm{M}$ by Day 10 , whereas phosphate concentrations remained above $0.3 \mu \mathrm{M}$. Silicic acid decreased by $6 \mu \mathrm{M}$ in the first $10 \mathrm{~d}$, and ammonium levels remained low throughout the experiment. Chlorophyll (chl) levels initially declined, but increased to ca $9.6 \mathrm{\mu g} \mathrm{l}^{-1}$ on Day 10 , after which they again decreased. Particulate matter concentrations increased dramatically (from 9.4 to $123 \mu \mathrm{mol} \mathrm{l^{-1 }}$ by Day 10 ; Fig. 2b); furthermore, they continued to increase after nitrate depletion and reached $240 \mu \mathrm{M}$ at the end of the experiment. Particulate organic nitrogen (PON) levels reached ca $21 \mu \mathrm{mol} \mathrm{l}^{-1}$ at the time of nitrate depletion and did not increase significantly thereafter. Bacteria grew exponentially throughout the experiment. The initial ambient bacterial biomass was low, and biomass increased at a net rate of $0.25 \pm 0.03 \mathrm{~d}^{-1}$ $\left(R^{2}=0.92 ; n=11\right)$ over $13 \mathrm{~d}$ to a peak

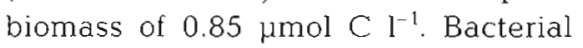
production was not determined during this experiment.

DOC was initially near the background level for the region (ca $42 \mu \mathrm{M}$ ), but by Day 10 nearly doubled to $80.6 \mu \mathrm{M}$ (Fig, 2c). DOC concentrations continued to increase after nutrient depletion in a manner similar to POC, and by the end of the experiment reached $261 \mu \mathrm{M}$. Increases in POC and DOC were highly correlated through- out the experiment ( $n=13 ; R^{2}=0.83 ; p<0.01$ ). To emphasize the partitioning of organic carbon between the particulate and dissolved phases, we calculated the ratio of the recently produced $\mathrm{DOC}\left(\mathrm{DOC}_{\mathrm{R}}\right)$ to total labile organic carbon $\left[\mathrm{TOC}_{\mathrm{R}}=(\mathrm{DOC}-42 \mu \mathrm{M})+\mathrm{POC}\right]$. This ratio initially was 0.18 (i.e. most of the recently produced organic material was in the particulate pool), but increased slightly during exponential growth, so that the average ratio for the experiment after Day 3 was 0.35. DOC as a percentage of TOC initially equaled 0.83 and decreased to 0.40 by Day 10 , when it slightly increased until the end of the experiment.

Ratios of various properties also varied in a systematic manner (Fig. 2d). For example, the POC/PON ratio ranged from 3.3 to $5.4(\mathrm{~mol} / \mathrm{mol})$ through Day 10, but increased to $7.9(\mathrm{~mol} / \mathrm{mol} ; 9.2 \mathrm{~g} / \mathrm{g})$ by the end of the experiment. Carbon:chlorophyll ratios were initially 42.3 and averaged 160 during the first $10 \mathrm{~d}$, but increased to 732 at the experiment's end. Nitrogen: chlorophyll ratios were 6.7 at the experiment's start, ca 45 during exponential growth, and 27.3 on Day 10 (the onset of non-detectable nitrate concentrations). Nitrate:phosphate ratios were ca 13.5 initially and decreased to 3.0 by Day 9, whereas $\mathrm{Si} \mathrm{NO}_{3}$ ratios were 2.6 at the start of the experiment. The bacterial contribution to the particulate carbon pool was at all times $<1 \%$

Phytoplankton growth rates were calculated from changes in particulate matter concentrations, decreases in nitrate concentrations, and from ${ }^{14} \mathrm{C}$-assimilation measurements combined with particulate matter determinations (Eppley 1967; Table 1). The greatest calculated daily growth rate resulted from the disappearance of nitrate during exponential growth $\left(0.69 \mathrm{~d}^{-1}\right)$, although the growth rate based on the initial and Day 14 nitrate concentrations equaled $0.42 \mathrm{~d}^{-1}$ Growth rates derived from particulate matter changes and ${ }^{14} \mathrm{C}$-isotope incorporation were less than the longterm nitrate-based growth rate (ca 0.26 and $0.35 \mathrm{~d}^{-1}$,

Table 1. Phytoplankton growth rates $\left(\mathrm{d}^{-1}\right)$ during exponential growth calculated from changes in nitrate and particulate matter concentrations and an exponential growth equation. Temperature-limited growth rate calculated from the equation of Eppley (1972) using the ambient seawater temperature $\left(-1.8^{\circ} \mathrm{C}\right)$. ${ }^{14} \mathrm{C}$-based rates represent mean during exponential growth

\begin{tabular}{lccc|}
\hline Variable used to derive growth rate & GCE94-1` & GCE94-2 & GCE95-1 \\
\hline Change in nitrate concentration & 0.49 & 0.09 & 0.22 \\
Change in POC concentration & 0.26 & 0.26 & 0.14 \\
Change in PON concentration & 0.27 & 0.24 & 0.14 \\
Change in chlorophyll concentration & 0.13 & 0.02 & -0.02 \\
POC concentration with ${ }^{14}$ C incorporation & 0.35 & 0.26 & No data \\
Temperature & 0.52 & 0.52 & 0.52
\end{tabular}

${ }^{a}$ Rates calculated from net changes from Days 0 to $10 ;{ }^{b}$ calculated from net changes from Days 0 to 7 ; ${ }^{C}$ calculated from net changes from Days 0 to 9 


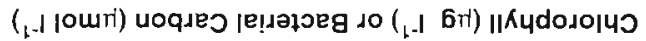

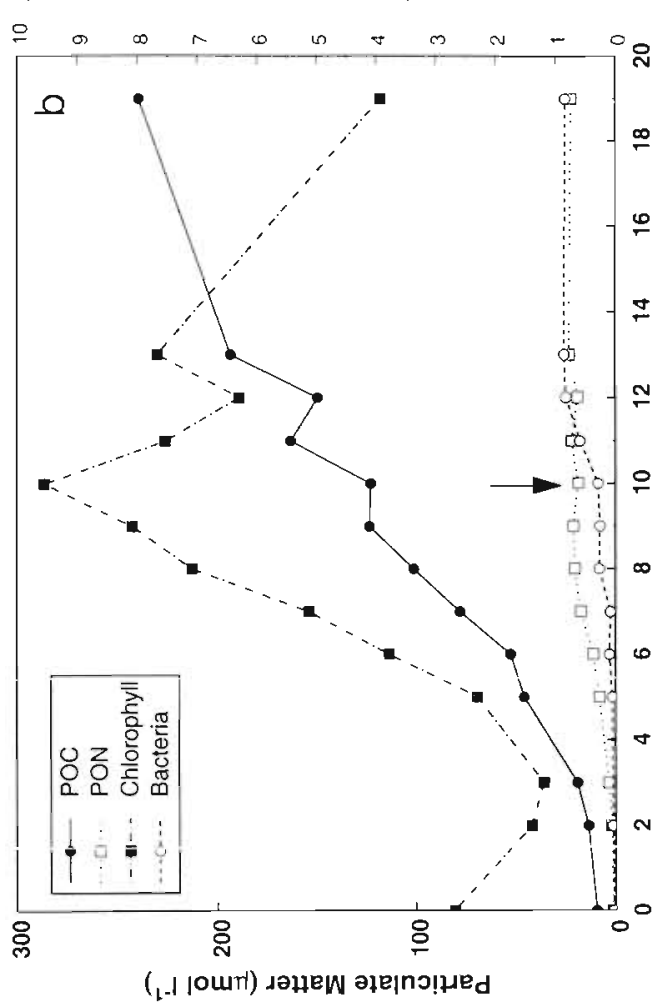

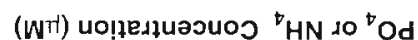

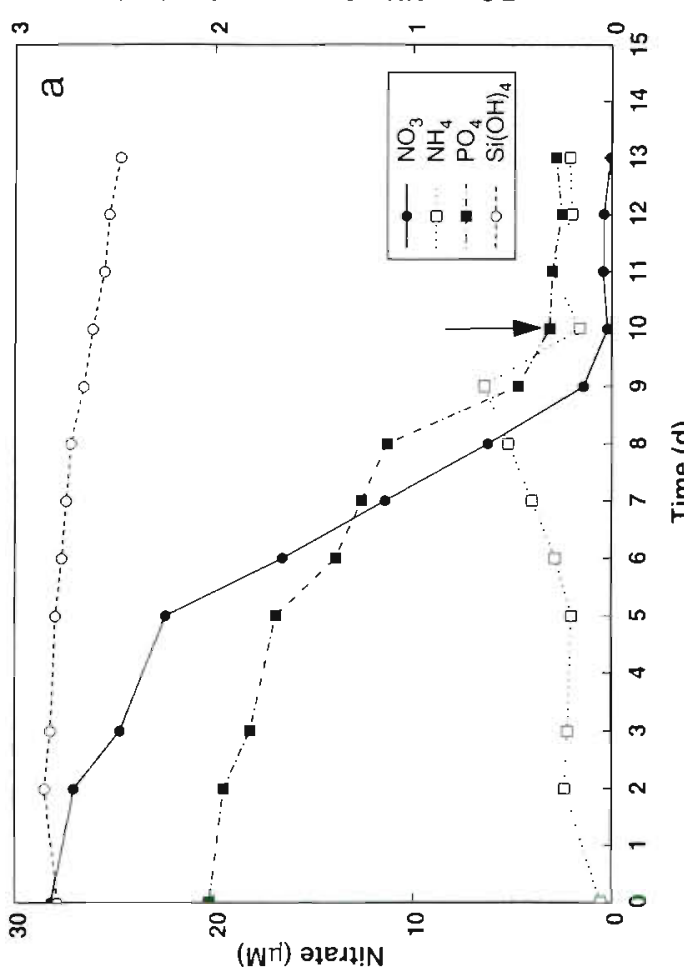

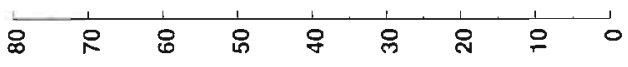

(Wri) ${ }^{t}$ (HO)!s

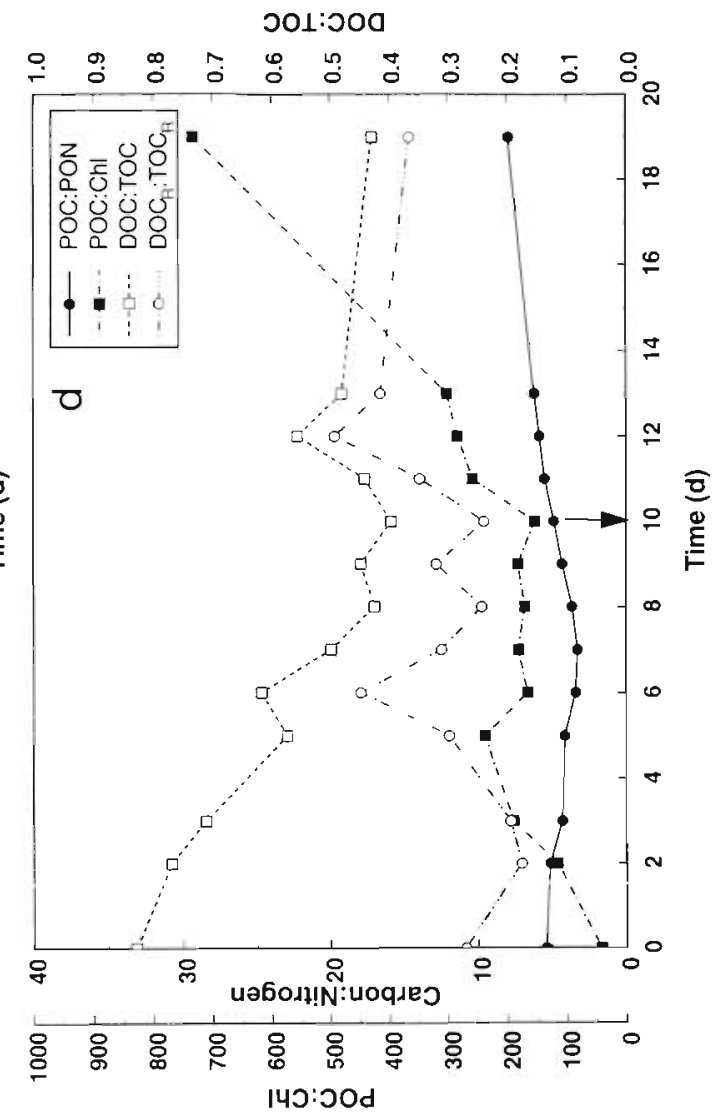

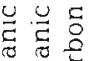
5

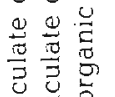

范苋高

동 $\frac{\pi}{0}$ (

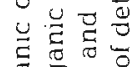

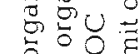
\&

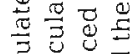

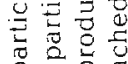

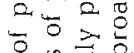
농 政嵌 플 过它 0 约 3

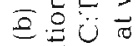

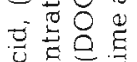
要 记 ज诺 릉 \& 0

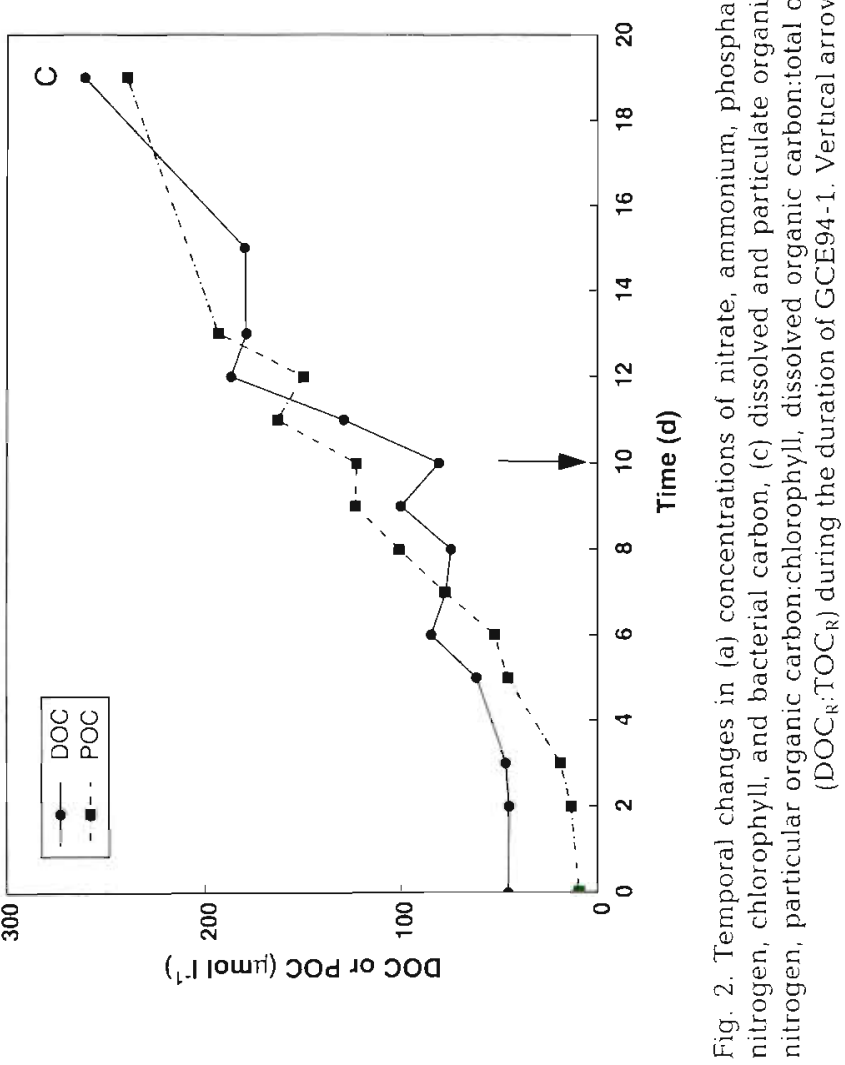


respectively), although growth rates calculated from PON changes from Day 3 through 7 averaged $0.44 \mathrm{~d}^{-1}$ For comparison, the predicted temperature-mediated growth rate is $0.52 \mathrm{~d}^{-1}$ (Eppley 1972).

\section{GCE94-2}

The second experiment in 1994 was initiated on 25 November to assess the exponential growth phase of the bloom and was started with larger initial concentrations of chlorophyll and particulate matter. Nitrate decreased over $7 \mathrm{~d}$ from 27.3 to $15.0 \mu \mathrm{M}$ (Fig. $3 \mathrm{a}$ ), and phosphate decreased concomitantly. Silicic acid decreased by $2 \mu \mathrm{M}$. Chlorophyll decreased by $40 \%$ during the first $2 \mathrm{~d}$, but increased thereafter to $4.21 \mathrm{\mu g} \mathrm{l}^{-1}$, a net increase of $11 \%$ in $7 \mathrm{~d}$ (Fig. 3b). POC concentrations, on the other hand, increased throughout the experiment, and after $7 \mathrm{~d}$ had increased 7 -fold to $83.3 \mu \mathrm{mol} \mathrm{l}^{-1}$ (Fig. 3b). DOC concentrations increased from 43 to $58 \mu \mathrm{M}$, and bacterial carbon increased by $350 \%$ (Fig. 3c). Bacterial abundance was somewhat higher than in GCE94-1, and bacteria grew at $0.17 \pm$ $0.02 \mathrm{~d}^{-1}\left(\mathrm{R}^{2}=0.91, \mathrm{n}=8\right)$ to a maximum concentration

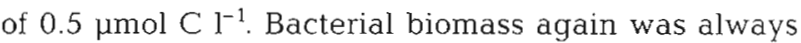
less than $1 \%$ of the total POC. The bacterial production

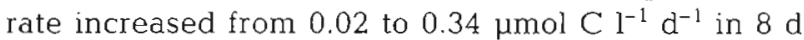
$\left(1.5\right.$ to $12.4 \mathrm{pmol}$ thymidine $\left.!^{-1} \mathrm{~h}^{-1}\right)$. Orer the course of the experiment, total cumulative bacterial production was equivalent to about $2 \%$ of the total primary production (calculated from hourly ${ }^{14} \mathrm{C}$ rates, assuming constant rates for primary production over each $24 \mathrm{~h}$ period).

Carbon:chlorophyll ratios increased dramatically during the experiment, but $\mathrm{C}: \mathrm{N}$ ratios did not change systematically (Fig. $3 \mathrm{~d}$ ). The $\mathrm{DOC}_{\mathrm{R}} / \mathrm{TOC}_{\mathrm{R}}$ ratio was zero on Day 1 and ranged from 0.1 to 0.2 thereafter, whereas the DOC/TOC ratio decreased from 0.73 to 0.40 , and then increased slightly. Growth rates were somewhat lower than observed in GCE94-1; rates calculated from particulate matter concentrations approached $0.25 \mathrm{~d}^{-1}$ (Table 1), with the exception of chlorophyll-based rate, which was much lower. Nitrate-based rates also were low $\left(0.08 \mathrm{~d}^{-1}\right.$; Table 1). The maximum sustained growth rate was observed from Day 1 through 4 and averaged $0.35 \mathrm{~d}^{-1}$ (based on PON changes)

\section{GCE95-1}

This experiment was initiated on 28 December with a large biomass $\left(7.4 \mu \mathrm{g} \mathrm{l}^{-1} \mathrm{chl}\right)$, with Phaeocystis antarctica again being the dominant species, although diatoms were also present. Nitrate concentrations de- creased from 21.7 to $<0.1 \mu \mathrm{M}$ on Day 15 , and silicic acid also decreased from 70.4 to $41.5 \mu \mathrm{M}$ (Fig. $4 \mathrm{a}$ ). Chlorophyll levels decreased to a minimum after $3 \mathrm{~d}$ (1.66 $\mu \mathrm{g}^{-1}$ ) but had increased by the end of the experiment to $11.1 \mathrm{\mu g} \mathrm{l}^{-1}$, whereas POC increased throughout (from 29.7 to $124 \mu \mathrm{mol} \mathrm{l} \mathrm{l}^{-1}$; Fig. $4 \mathrm{~b}$ ). $\mathrm{C} / \mathrm{N}$ ratios remained constant, but $\mathrm{POC} / \mathrm{chl}$ ratios increased from 45 to 325 (Fig. $4 \mathrm{C}$ ). DOC $/ \mathrm{R}$ TOC ratios again were low and did not exceed 0.13 at any time during the experiment, and DOC/TOC ratios were minimal at the end of the experiment (0.35). The initial bacterial biomass was about an order of magnitude greater than in 1994, and cells grew at $0.29 \pm 0.02 \mathrm{~d}^{-1}$ for the first $5 \mathrm{~d}\left(\mathrm{R}^{2}=0.98\right.$,

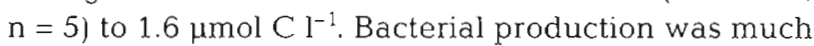
greater than in 1994, as expected from the higher biomass and faster growth rates. At the same time, primary production in the carboy (as in the field) was somewhat lower. In this experiment the cumulative bacterial production was equivalent to about $21 \%$ of the primary production integrated over $16 \mathrm{~d}$. At the time this experiment was started, the bloom may have been in the early stages of senescence, as suggested by the large numbers of attached bacteria. Bacterial biomass as a percentage of $\mathrm{POC}$ reached a maximum of $3 \%$ in this experiment, most as attached forms.

Estimated phytoplankton growth rates were less than those predicted based on temperature (Table 1). Growth rates based on chlorophyll were negative, reflecting the net decrease in chlorophyll over the first $9 \mathrm{~d}$. Nitrate-based growth rates were $0.22 \mathrm{~d}^{-1}$, whereas those based on particulate carbon and nitrogen changes were both $0.14 \mathrm{~d}^{-1}$. Maximum sustained growth rates (those which occurred for more than $3 \mathrm{~d}$ consecutively) were ca $0.25 \mathrm{~d}^{-1}$.

\section{Field observations}

The phytoplankton assemblages in 1994 along $76^{\circ} 30^{\prime} \mathrm{S}$ were dominated numerically and in terms of carbon equivalents by Phaeocystis antarctica. The earliest occupation of the transect (November 12 to 16 , 1994) was characterized by thin (ca 20 to $30 \mathrm{~cm}$ ) ice cover, variable stratification (Fig. 5a), modest particulate carbon concentrations (surface levels averaged 7.91 and ranged from 2.30 to $21.1 \mathrm{\mu mol} \mathrm{l}^{-1}$; Table 2) and chlorophyll concentrations, low bacterial abundances and carbon equivalents, and DOC concentrations at or slightly above deep water concentrations of $42 \mu \mathrm{M}$ (Table 2). Nitrate concentrations were elevated, but showed a small reduction at the surface (Fig. 5b); silicic acid concentrations were uniformly high (Table 2). Although stratification was not significantly stronger during early December, 1995 (Fig. 6a), the ice cover was gone, and phytoplankton biomass was near its maximum (mean 

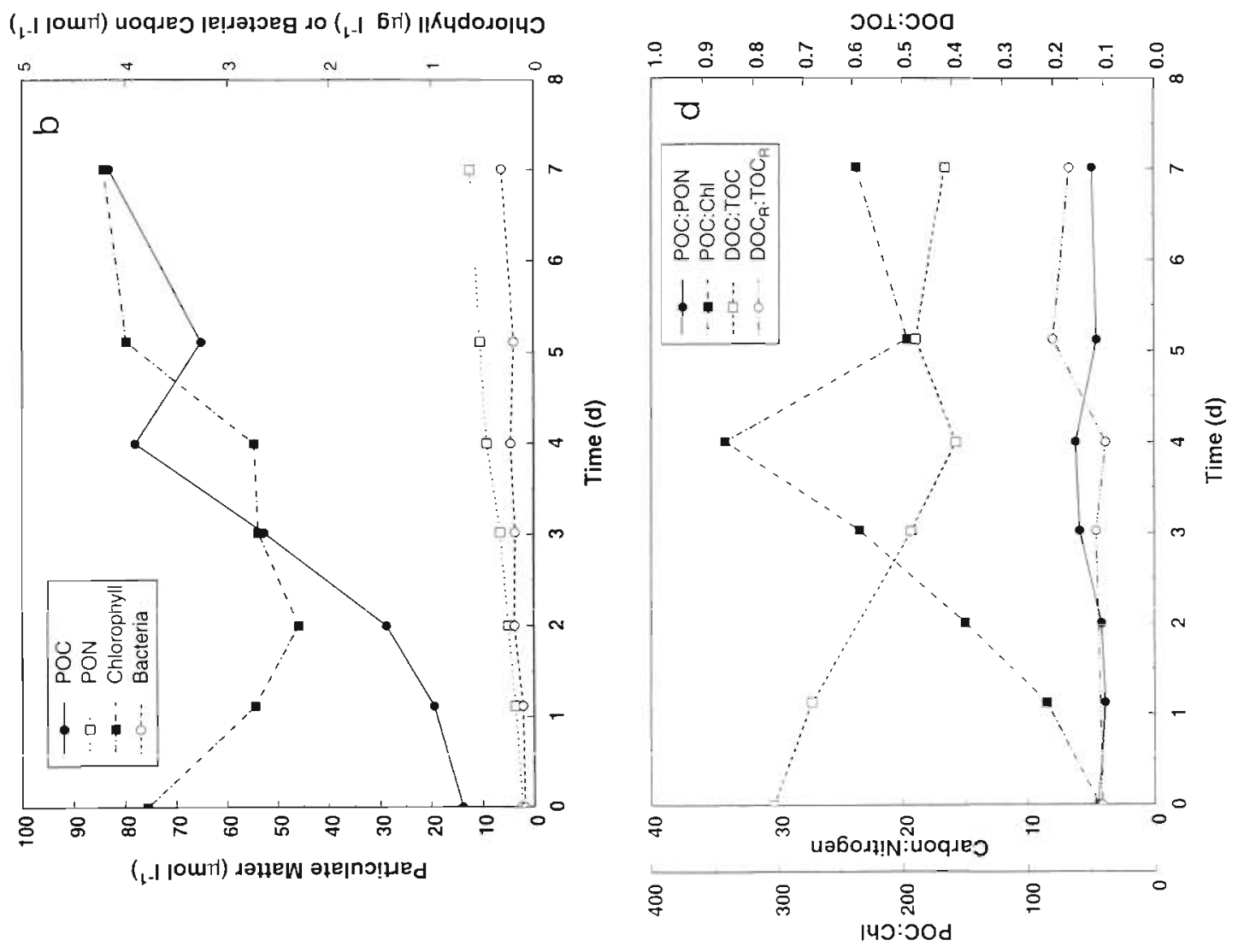

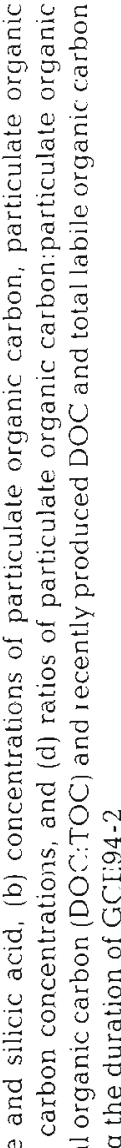

(wri) uo!pejpuəsuos ${ }^{\mathrm{t}} \mathrm{HN}$ do ${ }^{\mathrm{t}} \mathrm{Od}$
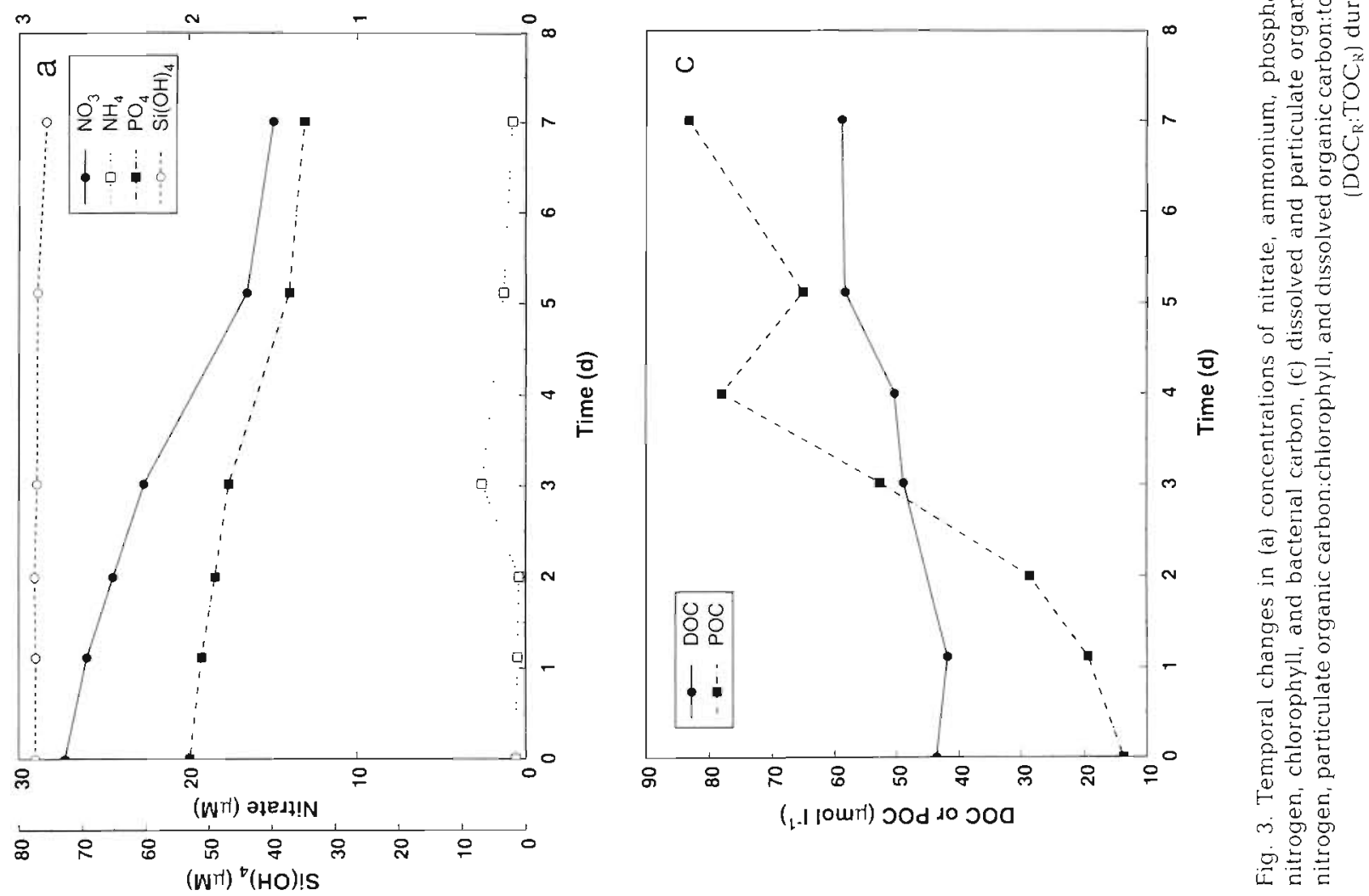


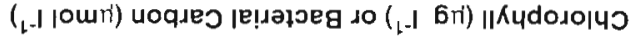

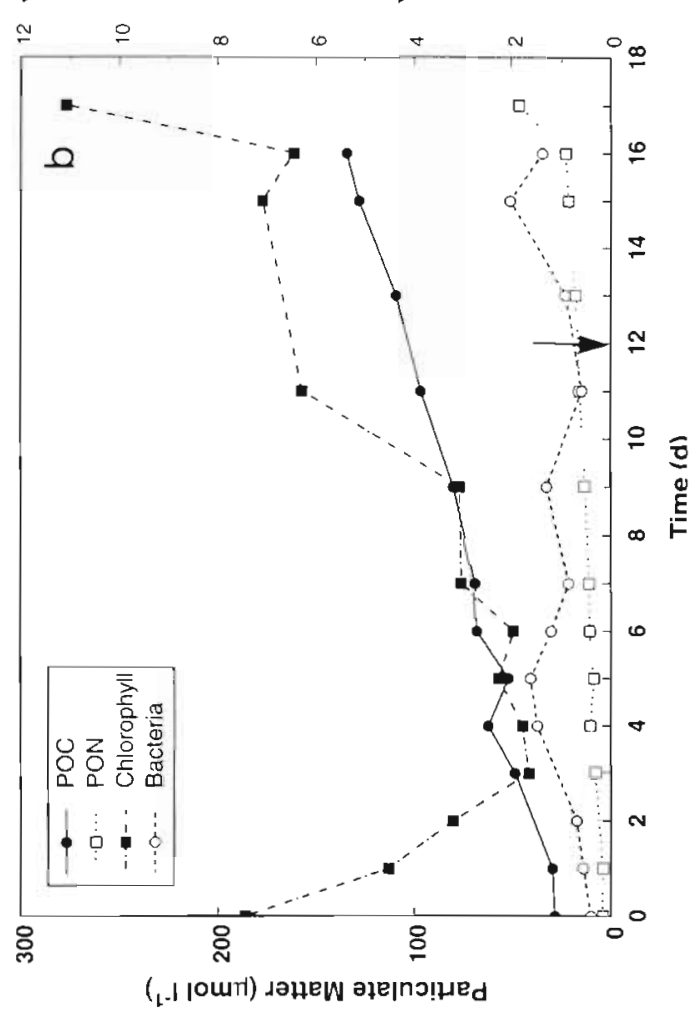

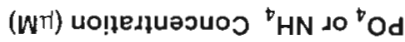

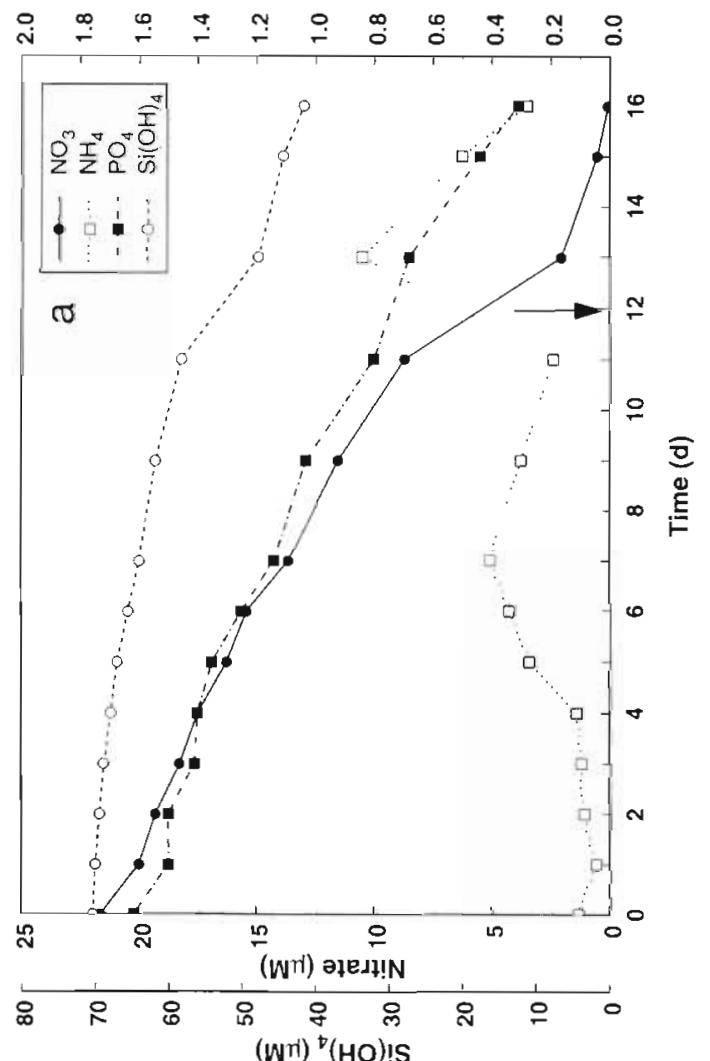

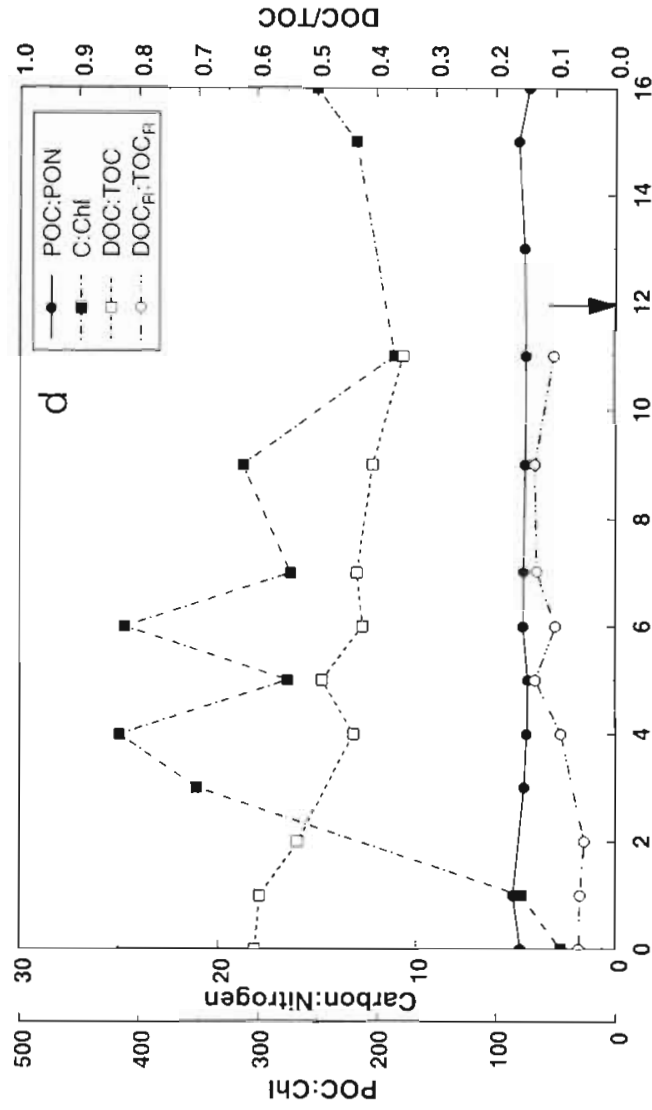

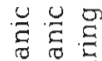

용

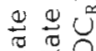

可苟

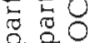

ह

要要

$\because 0$

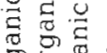

논

(1) 0

$\infty \stackrel{0}{\circ} \stackrel{0}{\sigma} \stackrel{0}{0}$

글

范范

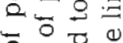

용

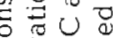

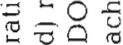

- 0

Ч

บ

원을

ర롱

บ 0

记完

¿0

\%

9.0

范

is 응응

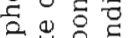

E $\frac{\pi}{3}$ 范

吾记

5 范

용

흔

政

$\stackrel{Ð 00}{0}$

릉

ธ色艺岂

으응

$\because \pi^{\circ}$

동용

苟氙

$5 \frac{\pi}{2}$

os

\%

$\Xi \subseteq$

(1) 롱

을 흔

증

운응

$\stackrel{0}{\circ}$

$\rightarrow$ D

实茪 

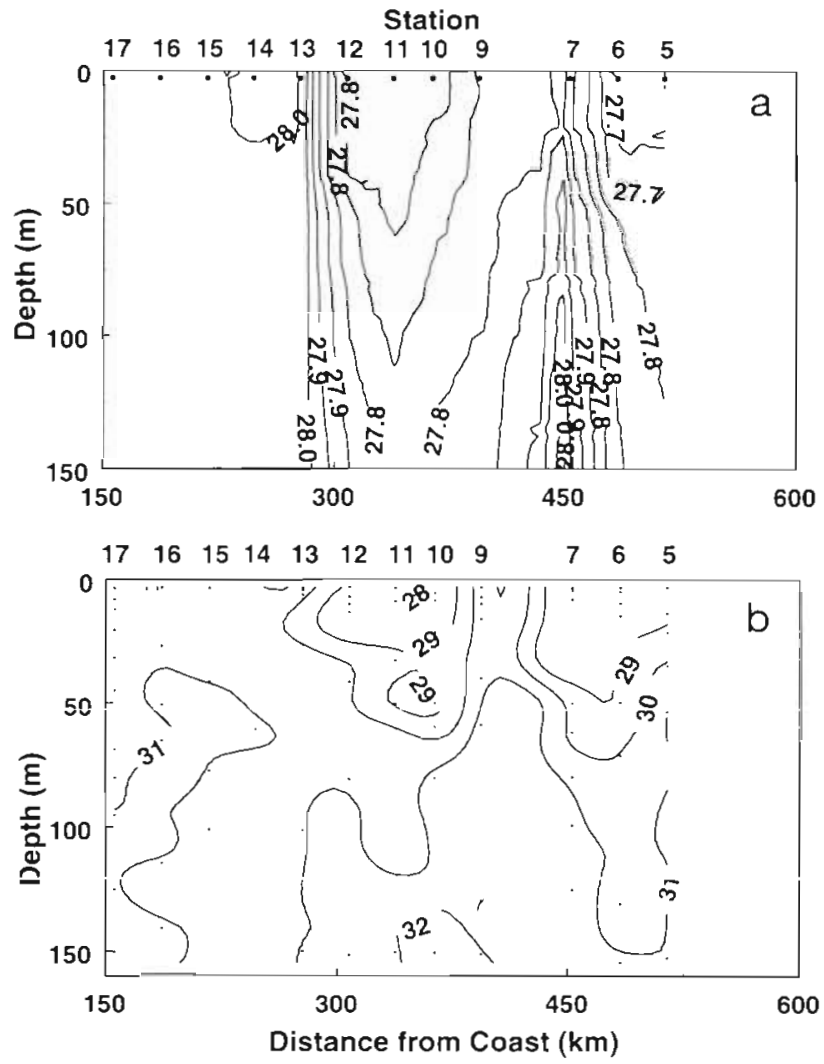

Fig. 5. Vertical distribution of (a) density (expressed as $\sigma_{t}$ ) and (b) nitrate $(\mu \mathrm{M})$ during November 8 to 12,1994

POC concentration $=23.0 \mu \mathrm{mol} \mathrm{l}^{-1} ;$ Table 2 ). Bacterial abundance increased slightly, as did DOC concentrations (Table 2). Nitrate concentrations throughout the surface layer decreased substantially (Fig. 6b), and silicic acid still did not change greatly (Table 2).

The last occupation of the transect in 1995 showed marked stratification (Fig. 7a), decreased particulate matter concentrations, increased bacterial abundances, low DOC concentrations (Table 2), and substantially diminished nitrate levels (Fig. 7b). Chlorophyll levels were only $31 \%$ of the maximum values in 1994 (Table 2), and silicic acid concentrations had decreased slightly. The assemblage still had large numbers of Phaeocystis antarctica cells, but the abundance (absolute and relative) of diatoms also increased markedly.

The ratios of variables also changed significantly through time (Table 2). For example, the carbon:chlorophyll ratio increased from 64 to 126, and the bacterial carbon:particulate carbon ratio also increased substantially (from 6.3 and $11.0 \%$ in November and December to $58 \%$ in late January). The proportion of DOC relative to TOC decreased from 0.85 in midNovember to 0.68 and 0.71 in the 2 later cruises, and
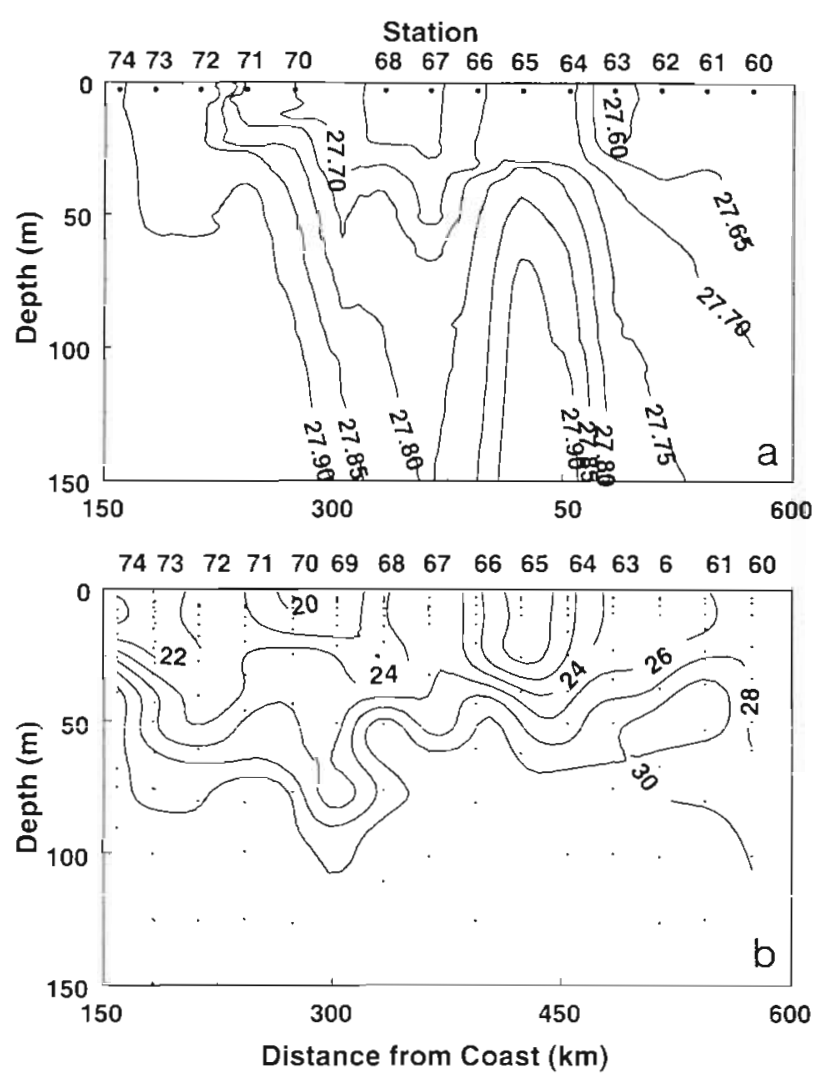

Fig. 6. Vertical distribution of (a) density (expressed as $\sigma_{t}$ ) and (b) nitrate $(\mu \mathrm{M})$ during December 5 to 8,1994

the percentage of recently produced DOC relative to total 'new' organic matter also decreased. N/P ratios were similar in all cruises and ranged from 13.4 to 14.0.

\section{DISCUSSION}

\section{Enclosure experiments}

The enclosure experiments provided insights into the carbon and nitrogen partitioning patterns of planktonic communities dominated by Phaeocystis antarctica. We had hypothesized that P. antarctica would produce and release large amounts of dissolved organic matter, similar to communities dominated by P. pouchetii in the North Sea (Lancelot \& Mathot 1987). However, the enclosures did not produce exceptionally large DOC accumulations during exponential growth; indeed. DOC levels during the first experiment doubled by the time of nitrate depletion, and in the other 2 experiments only increased by 40 and $23 \%$, respectively. These changes in DOC are within the range of seasonal variation seen in other regions (e.g. Carlson \& Ducklow 1995, Peltzer \& Hayward 1996). POC con- 


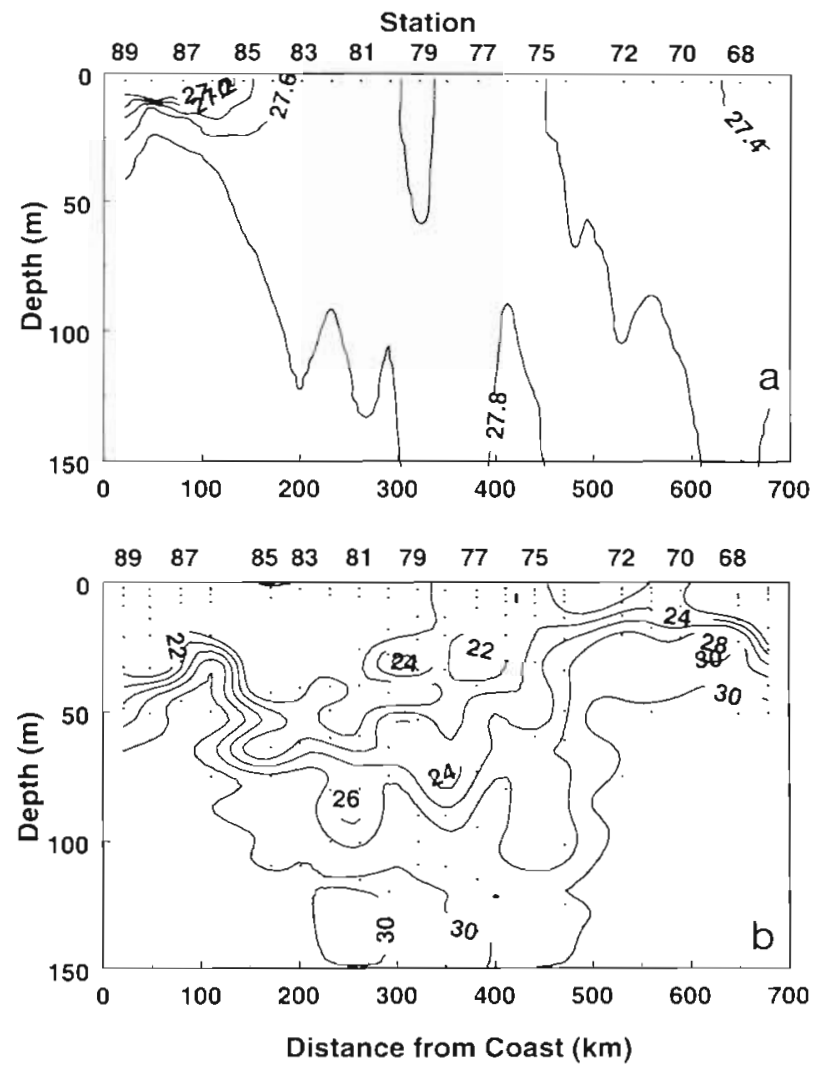

Fig. 7. Vertical distribution of (a) density (expressed as $\sigma_{1}$ ) and (b) nitrate ( $\mu M$ ) during January 16 to 19,1996

centrations, on the other hand, increased by over an order of magnitude in the first experiment, and by 600 and $470 \%$ in the latter 2 experiments. Clearly most of the organic material being produced by photosynthesis was being partitioned to the particulate phase.

POC and DOC production continued unabated after nitrate depletion. POC concentrations doubled after Day 10 in GCE94-1 and DOC levels tripled (Fig. 2b, c). PON levels, however, did not increase, which suggests that carbon and nitrogen production and metabolism largely became uncoupled during this period. As a result, POC/PON ratios increased significantly upon nutrient depletion. We believe that upon nitrate depletion Phaeocystis antarctica continued to fix carbon and shunt much of the organic material into the mucoid sheath (Chrétiennot-Dinot et al. 1997), and protein and cellular synthesis largely ceased. Goldman et al. (1992) found that some laboratory cultures of diatoms also continued to fix carbon and release DOC, despite the absence of available nitrogen. Banse (1994) also found that carbon assimilation continued after nitrogen depletion in natural assemblages of phytoplankton, whereas Smith et al. (1995) found that particulate and total organic carbon leveled off upon nutrient depletion. The uncoupling of carbon fixation and nutrient
Table 2. Mean surface concentrations of various particulate and dissolved parameters within the $76^{\circ} 30^{\prime} \mathrm{S}$ transect and their standard deviations. Range of observations in parentheses

\begin{tabular}{|c|c|c|c|}
\hline Variable & $\begin{array}{c}\text { Nov } 12-15 \\
1995\end{array}$ & $\begin{array}{c}\text { Dec } 8-12 \\
1995\end{array}$ & $\begin{array}{c}\operatorname{Jan} 16-20 \\
1996\end{array}$ \\
\hline Nitrate $(\mu \mathrm{M})$ & $\begin{array}{c}29.5 \pm 1.04 \\
(23.3-31.0)\end{array}$ & $\begin{array}{c}23.5 \pm 3.1 \\
(18.8-28.9)\end{array}$ & $\begin{array}{r}19.2 \pm 0.44 \\
(10.8-25.2)\end{array}$ \\
\hline Phosphate $(\mu \mathrm{M})$ & $\begin{array}{c}2.10 \pm 0.05 \\
(2.03-2.18)\end{array}$ & $\begin{array}{c}1.76 \pm 0.15 \\
(1.54-1.99)\end{array}$ & $\begin{array}{r}1.42 \pm 0.33 \\
(0.59-1.84)\end{array}$ \\
\hline Silicic acid $(\mu \mathrm{M})$ & $\begin{array}{c}77.1 \pm 1.86 \\
(72.3-78.9)\end{array}$ & $\begin{array}{c}73.5 \pm 3.1 \\
(68.3-77.1)\end{array}$ & $\begin{array}{r}60.3 \pm 8.24 \\
(34.2-68.5)\end{array}$ \\
\hline Ammonium $(\mu \mathrm{M})$ & $\begin{array}{c}0.09 \pm 0.10 \\
(0.00-0.44)\end{array}$ & $\begin{array}{c}0.10 \pm 0.05 \\
(0.03-0.23)\end{array}$ & $\begin{array}{c}0.30 \pm 0.15 \\
(0.10-0.66)\end{array}$ \\
\hline Chlorophyll $\left(\mu \mathrm{g}^{-1}\right)$ & $\begin{array}{c}1.49 \pm 1.08 \\
(0.15-2.88)\end{array}$ & $\begin{array}{c}5.75 \pm 2.65 \\
(1.17-11.5)\end{array}$ & $\begin{array}{r}1.77 \pm 1.29 \\
(0.31-4.68)\end{array}$ \\
\hline $\begin{array}{l}\text { Particulate organic } \\
\text { carbon }\left(\mu \mathrm{mol} \mathrm{l}^{-1}\right)\end{array}$ & $\begin{array}{l}7.91 \pm 5.08 \\
(2.30-21.1)\end{array}$ & $\begin{array}{c}23.0 \pm 12.9 \\
(8.07-46.1)\end{array}$ & $\begin{array}{c}18.6 \pm 5.44 \\
(8.33-29.6)\end{array}$ \\
\hline $\begin{array}{l}\text { Particulate organic } \\
\text { nitrogen }\left(\mu \mathrm{mol} \mathrm{l}^{-1}\right)\end{array}$ & $\begin{array}{c}1.05 \pm 0.47 \\
(0.32-1.77)\end{array}$ & $\begin{array}{c}3.86 \pm 2.08 \\
(1.41-7.81)\end{array}$ & $\begin{array}{r}2.99 \pm 0.83 \\
(1.37-4.90)\end{array}$ \\
\hline 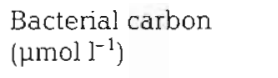 & $\begin{array}{c}0.50 \pm 0.20 \\
(0.29-1.00)\end{array}$ & $\begin{array}{c}2.50 \pm 2.41 \\
(0.43-8.91)\end{array}$ & $\begin{array}{c}10.7 \pm 3.04 \\
(3.83-14.2)\end{array}$ \\
\hline $\begin{array}{l}\text { Dissolved organic } \\
\text { carbon }(\mu \mathrm{M})\end{array}$ & $\begin{array}{c}44.9 \pm 2.10 \\
(43.1-49.2)\end{array}$ & $\begin{array}{c}48.7 \pm 10.3 \\
(41.8-72.9)\end{array}$ & $\begin{array}{c}46.2 \pm 2.40 \\
(43.4-52.3)\end{array}$ \\
\hline$P O C: \mathrm{chl}^{a}(w / w)$ & 63.7 & 48.0 & 126 \\
\hline POC:PON ${ }^{\circ}(\mathrm{mol} / \mathrm{mol})$ & 7.53 & 5.96 & 6.22 \\
\hline DOC:TOC ${ }^{a}(\mathrm{~mol} / \mathrm{mol})$ & 0.85 & 0.68 & 0.71 \\
\hline $\mathrm{DOC}_{\mathrm{R}}: \mathrm{TOC}_{\mathrm{R}}{ }^{\mathrm{a}}(\mathrm{mol} / \mathrm{mo}$ & ol) 0.28 & 0.23 & 0.19 \\
\hline
\end{tabular}

acquisition we observed confounds the concept of carbon-based new production, since the organic carbon fixation which occurred in the absence of nitrogen assimilation represented a significant percentage of the total carbon production. Also, this carbon uptake relative to nutrient uptake clearly was not near the Redfield ratio, and material which might be removed from the surface would have greatly skewed elemental composition (Sambrotto et al. 1993). Further investigation on the significance of non-Redfieldian uptake is warranted in other Antarctic systems.

Chlorophyll was a poor indicator of phytoplankton biomass in the enclosures and responded rapidly to a changed irradiance environment. Although the original inocula were obtained from the surface layer, the sampled water column was mixed to a much greater depth (the mixed layer in general extended to at least the $5 \%$ isolume), and hence the in situ populations were likely exposed to variable irradiances through time. When maintained in a constant and high irradiance environment, Phaeocystis antarctica adapted its photosynthetic pigmentation by increasing the carbon:chlorophyll ratio. In 3 experiments the $\mathrm{POC} / \mathrm{chl}$ ratio was initially ca 45 , but within 24 h the ratio increased dramatically (at least doubling in all cases). 
This parallels what generally is expected from culture and modeling experiments, where the amount of chlorophyll and photosynthetic reaction centers per unit of carbon decrease under high photon flux densities (e.g. Prézelin 1981, Kirk 1994). However, what is somewhat surprising is the extent to which $P$. antarctica assemblages modify this ratio. In all experiments prior to extreme colony disintegration (Day 19, GCE94-1), the ratio ranged from 237 to 316 , which is much greater than is normally observed in temperate and tropical waters (e.g. Bannister \& Laws 1983). It is, however, similar to those found in the Ross Sea previously (Smith \& Nelson 1985, Smith et al. 1996), and consistent with pigment labeling experiments conducted in the same region (DiTullio \& Smith 1996). High carbon:chlorophyll ratios also can result from substantial amounts of detrital material being present, but based on the $\mathrm{C} / \mathrm{N}$ ratios we observed as well as microscopic observations, detrital (i.e. POC not associated with cells or colonies) contributions were exceedingly small, especially during exponential growth. Elevated Poc./chl ratins apnear to he consistent.; ubiquitous adaptations of Ross Sea phytoplankton to the irradiance and/or nutrient fields present.

Bacteria grew exponentially at 0.17 to $0.29 \mathrm{~d}^{-1}$ in the 3 experiments, all of which represented untreated (i.e. no removal of bacteriovores) water samples. Exponential growth at these substantial rates in 'whole' water suggests that bacterial growth was not strongly limited by bacterivory (Ducklow et al. 1992). If we assume that the bacterial growth efficiency was 15 to $20 \%$, we can estimate that in GCE2-94 an amount of carbon equivalent to about 10 to $15 \%$ of the total primary production was metabolized by bacteria in the carboy. Phytoplankton biomass and DOC both increased throughout the experiment, except for a transient POC decline of

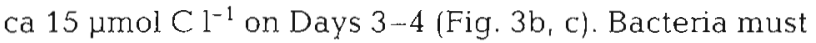
have been sustained by a flux of newly produced carbon, or by only minor utilization of existing pools. In 1995 the same assumption about growth efficiency would lead us to estimate that nearly all the primary production was metabolized by bacteria during the $16 \mathrm{~d}$ experiment. This is unlikely, and we suggest that bacterial growth efficiency was greater in this experiment, with higher growth rates and biomass accumulation resulting, compared to 1994

Smith et al. (1995) conducted similar experiments in mesocosms initiated with water from off the coast of California, and they investigated the bacterial-diatom interactions in the resultant bloom. They did not observe that phytoplankton production and particulate/total organic carbon concentrations continued after nutrient depletion, but rather leveled off. They also found that bacterial carbon demand was estimated to be from 40 to $60 \%$ of the total carbon fixed during the bloom, in contrast to our estimation of 10 to $15 \%$ in GCE94-2. Attached bacteria within their bloom were suggested as being highly significant in solubilizing DOC from particles, despite their being a small percentage of total bacteria. We did find a variation in the relative proportion of attached bacteria in the water used to initiate the experiments, with GCE95-1 having the largest proportion of attached bacteria. We have no data on the relative activity of the bacterial fractions, but it certainly is possible that attached bacteria were active in oxidizing and utilizing the extracellular mucilage of Phaeocystis antarctica, and that this DOC production mechanism varies as a function of bloom development and physiological state.

Initial DOC/TOC ratios were high (approximately 0.75 in all experiments) and decreased as particulate matter generation proceeded. These ratios reflected the dominance of particulate production over dissolved production on the time scales of the experiment. Most systems have ratios of ca 0.9 (Hobson et al. 1976), implying that the largest organic carbon pool is usually DOC. In these enclosures this was not true during high biomass stages, where the particulate phase increased relative to DOC. Carlson et al. (1998) suggested that the DOC production mechanisms which dominate during a Phaeocystis antarctica bloom result in limited DOC production; furthermore, the DOC which is produced is readily mineralized by bacterioplankton, resulting in limited accumulation of the DOC pool. Van Rijssel et al. (1997) suggest that $P$. globosa (and by extension other Phaeocystis spp.) have an aqueousrather than mucus-filled lumen in the colony, and that carbohydrate is just a small part of the colonial biomass. Our results of minor DOC production are consistent with this observation. The ratios of the recently produced pools of organic matter generated within the enclosures $\left(D O C_{R}\right.$ and $\left.\mathrm{TOC}_{\mathrm{R}}\right)$ were also low, but increased slightly after nutrient depletion and with time. This suggests that the DOC being produced during senescence may have been slightly more refractory and accumulated in greater quantities than during exponential growth of phytoplankton, which in turn may imply that the material is highly enriched with carbon relative to nitrogen and hence is a 'poorer' substrate for bacterial catabolism.

Because the enclosures were closed systems, it is possible to construct a nitrogen budget and estimate the amount of DON produced during the course of the experiment (Fig. 8). More specifically, because the initial amounts of nitrate, nitrite, ammonium and particulate organic nitrogen are known, the sum of these pools should not change through time, and any disappearance' of nitrogen must (in the absence of denitrification) enter into the DON pool. Therefore, DON (recently produced DON) produced during the experi- 


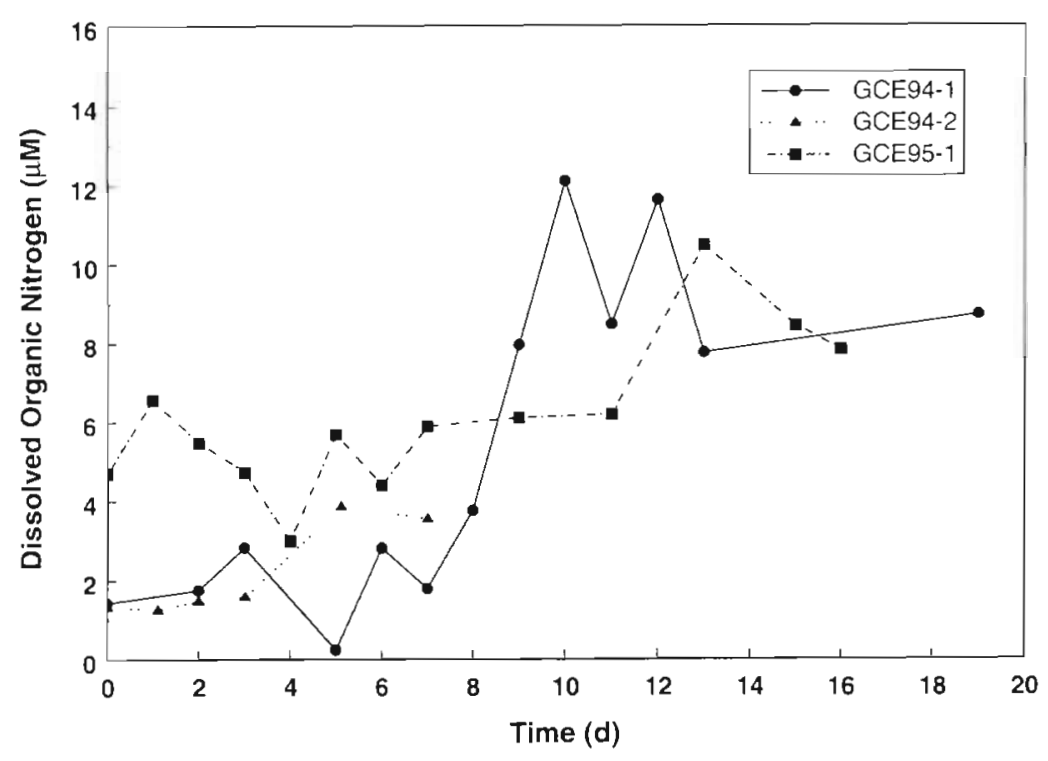

Fig. 8. Calculated (from Eq. 1) changes in recently produced dissolved organic nitrogen during the 3 enclosure experiments

ment can be calculated as

$$
\mathrm{DON}_{\mathrm{R}}=31.0-\left(\mathrm{NO}_{3}+\mathrm{NO}_{2}+\mathrm{NH}_{4}+\mathrm{PON}\right)
$$

where 31.0 represents the baseline (i.e. sum of all dissolved nitrogen forms) value. During GCE94-1 DON accumulation was low and fairly constant during exponential growth, but rapidly began to increase as nitrate concentrations approached limiting levels. During senescence $\mathrm{DON}_{\mathrm{R}}$ pools exceeded $10 \mu \mathrm{M}$ and did not change markedly thereafter. During GCE94-2 DON $N_{R}$ did not exceed $3.9 \mu \mathrm{M}$, whereas in GCE95-1 $\mathrm{DON}_{\mathrm{R}}$ remained at low concentrations prior to nutrient depletion but again increased substantially as nitrate disappeared (Fig. 8). These results suggest that DON production in the Ross Sea is likely to be quantitatively minor, a finding corroborated by direct $\mathrm{DO}^{15} \mathrm{~N}$ release measurements made by $\mathrm{Hu} \&$ Smith (1998)

An alternate pathway for nitrogen in the enclosures would involve the generation of gaseous $\mathrm{N}_{2} \mathrm{O}$ during the process of nitrification. Although nitrification rates can be substantial in surface waters (e.g. Dore \& Karl 1996), there are no data to suggest that these rates also occur in the cold, surface layer of the Southern Ocean. Furthermore, the sum of all nitrogen forms in the enclosures was constant through time, which strongly suggests that no gaseous forms of inorganic nitrogen were being generated during the course of the experiments.

\section{Comparison of experimental and field data}

Many of the variables sampled in the field were markedly different from those observed in the en- closures, despite the overwhelming dominance of Phaeocystis antarctica in both. One of the most striking features was that nitrate never was depleted to the non-detectable levels found in the enclosures. The mean surface nitrate concentration in late January was 19.2 $\mu \mathrm{M}$ (Table 1), and studies completed later in the seasonal cycle suggest that although further nitrate uptake occurs, nitrate rarely declines below $10 \mu \mathrm{M}$ (Smith et al. 1996). Phytoplankton do not deplete nitrate from the surface layer, and hence do not experience conditions which would stimulate large changes in their nitrogenous metabolism. It has been hypothesized that in situ concentrations of iron might limit phytoplankton growth and biomass in the Ross Sea (e.g. Sedwick \& DiTullio 1997), and because our experiments were not intended to be free of trace-metal contaminants, they should be considered as trace-metal replete. PON levels in the surface layer were much less than those observed in the enclosures (reaching $21 \mu \mathrm{M}$ in the enclosures but averaging $3.86 \mu \mathrm{M}$ during the biomass maximum period in December; Table 2), as were POC levels (193 vs 23.0 ॥M). Chlorophyll levels, however, were similar in the two, with maximum chlorophyll levels in the field reaching $11.5 \mathrm{\mu g} \mathrm{I}^{-1}$, whereas the maximum in the enclosures was $9.6 \mu \mathrm{g} \mathrm{l^{-1 }}$.

Bacteria generally grew faster and reached higher levels in the experimental enclosures than was observed in the field at the same time. For example, in 1994 bacteria in the upper $150 \mathrm{~m}$ of the water column grew at about $0.05 \mathrm{~d}^{-1}$ and reached peak abundances of ca 0.5 to $1 \times 10^{9}$ cells $l^{-1}$, which was about half of the maximum abundance seen in the enclosures. We suggest that in the experiments the combined effects of a greater photon flux and possibly the resulting nutrient depletion enhanced DOC production by Phaeocystis and other phytoplankton, and this in turn fostered faster bacterial growth rates and higher standing stocks. Bacterial production in situ was greater in 1995 , so in this respect, the enclosures reflected the trends observed in the water column.

Field constituent ratios were also different than those found in enclosures. Average POC/chl ratios in the field ranged from 48.0 to 126 , which were substantially lower than in the enclosure. We believe the difference represents the difference in the photoadaptative abilities of Phaeocystis as influenced by the nutrient and irradiance regime. Field populations always had excess nitrate available, whereas the enclosed populations did not. Furthermore, the enclo- 
sures were incubated on deck in full sunlight (which averaged ca $50 \mu \mathrm{mol}$ photons $\mathrm{m}^{-2} \mathrm{~d}^{-1} ; \mathrm{Hu} \&$ Smith in press), and hence the average irradiance experienced by the in situ populations was much less (probably by at least 2 orders of magnitude). The constant, high irradiance environment allowed the cells to adapt their photosynthetic machinery to high photon flux densities, and the elevated POC/chl ratios reflect that adaptation. Similarly, the mean molar POC/PON ratio at the surface during the 3 transects ranged from 5.96 to 7.53 , whereas in the enclosures the ratios were generally much lower (between 3.5 and 5.0). The difference again may be adaptive, with in situ populations that are growing more slowly having relatively less protein than those growing at maximal rates. However, Lancelot et al. (1986) found little relationship between irradiance and protein synthesis for natural assemblages dominated by Phaeocystis, and Terry et al. (1983) found increased amounts of protein at low irradiances, although most of the variation was attributed to changes in other (non-nitrogenous) cellular constituents.

DOC concentrations in the field were also much lower than those which we found in the experimental enclosures. DOC levels averaged 44.9, 48.7, and $46.2 \mu \mathrm{M}$ in the surface layer during the 3 transects, but reached $187 \mu \mathrm{M}$ during GCE94-1 Similarly, although dissolved and particulate pools were strongly correlated in the enclosures, no such correlation was found in the surface layer. This suggests that the release rates of DOC in the field may have been lower than in the enclosures, and/or the bacterial populations were more capable of maintaining the lower DOC concentrations in the field. This latter explanation seems unlikely, since bacterial growth rates and biomass were enhanced in the experimental enclosures, but could not suppress DOC accumulation.

Phaeocystis blooms are regular occurrences in many regions of the world, including the North Sea, the Bering Sea continental shelf break, the Greenland Sea and other Antarctic coastal systems such as Prydz Bay (Lancelot et al. 1998). The North Sea environment appears radically different, in that the bloom is stimulated by coastal run-off and appears to become phosphorus limited in shallow waters. The copious DOC release found in the North Sea contrasts markedly with what has been observed in the Ross Sea (Carlson et al. 1998), but is much more similar to that found in the enclosures when nutrient limitation is reached. We suggest that the limitation of cell biomass production (in contrast to extracellular mucoid sheath production) induced by low ambient nutrient concentrations uncouples cellular production from carbon assimilation. As a result, overall carbon production continues, and approximately half of this production immediately enters the DOC pool (and larger amounts of DOC may ultimately be created through partial remineralization and solubilization of particles).

Phaeocystis antarctica is found throughout the waters surrounding Antarctica and often forms massive blooms early in the growing season. It generally is not grazed by mesozooplankton, and colonies in the Ross Sea appear to be grazed by microzooplankton at only low rates (Caron et al. unpubl.). As a result, its presence can greatly modify the local food web and surface layer carbon transformations. In addition, the dominant mechanism by which it exits the mixed layer is by sinking of large colonies and/or the formation of large aggregates from colonial material. These colonies and aggregates are thought to be largely degraded within the water column and hence represent only a seasonal sink for carbon rather than long-term removal within the carbon cycle. Some material does reach the sediments (Dunbar et al. 1998, Smith \& Dunbar 1998), but quantitatively it is much less than in diatom assemblages where grazing produces rapidly sinking fecal material, which in large part is not degraded within the water column. Hence $P$. antarctica can markedly structure the carbon transformations in areas where it reaches substantial biomass levels. Our results suggest that the environmental influences on Phaeocystis growth and composition are significant, and that the fluxes of carbon between pools within Phaeocystisdominated assemblages are often difficult to directly observe. Further understanding of the controls on $P$. antarctica growth and development will provide insights into the structure and function of polar continental systems and into the importance of the Southern Ocear within the global carbon cycle.

Acknowledgements. This research was supported by the National Science Foundation grants OPP-9317587, 9319222 and 9317200 . We thank Dr L. Gordon for nutrient analyses. Expert technical help was provided by A.-M. White, S. Polk, H. Quinby, A. Bryant, M. Church, L. Monty, A. Ritchie, T Tredennick and R. Parsons

\section{LITERATURE CITED}

Arrigo KR, McClain CR (1994) Spring phytoplankton production in the Western Ross Sea. Science 266:261-263

Bannister TT, Laws EA (1983) Modeling phytoplankton carbon metabolism. In: Falkowski PG (ed) Primary productivity in the sea. Plenum Press, New York, p 243-258

Banse K (1994) Uptake of inorganic carbon and nitrate by manne plankton and the Redfield ratio. Global Biogeochem Cycles 8:81-84

Becquevort S (1997) Nanoprotozooplankton in the Atlantic sector of the Southern Ocean during early spring: biomass and feeding activities. Deep Sea Res II 44:355-373

Brussard CPD, Gast GJ, van Duyl FC, Riegman D (1996) Impact of phytoplankton bloom magnitude on a pelagic microbial tood web. Mar Ecol Prog Ser 144:211-221 
Burkill PH, Edwards ES, Sleigh MA (1995) Microzooplankton and their role in controlling phytoplankton growth in the marginal ice zone of the Bellingshausen Sed. Deep Sea Res II 42:1277-1290

Cadée GC (1990) Increased bloom. Nature 346:418

Carlson CA, Ducklow HW (1995) Dissolved organic carbon in the upper ocean of the central equatorial Pacific Ocean, 1992: daily and fine scale vertical variations. Deep Sea Res II 42:639-656

Carlson CA, Ducklow HW (1996) Growth of bacterioplankton and consumption of dissolved organic carbon in the Sargasso Sea. Aquat Microb Ecol 10:69-85

Carlson CA, Ducklow HW, Hansell DA, Smith WO Jr (1998) Organic carbon partitioning during spring phytoplankton blooms in the Ross Sea polynya and the Sargasso Sea. Limnol Oceanogr 43:375-386

Chrétiennot-Dinot J, Giraud-Guille M, Vaulot D, Putaux JL, Saito Y, Chanzy H (1997) The chitinous nature of filaments ejected by Phaeocystis. J Phycol 33:666-672

Davidson AT, Marchant HJ (1992) Protist abundance and carbon concentration during a Phaeocystis-dominated bloom at an Antarctic coastal site. Polar Biol 12:387-395

DiTullio GR, Smith WO Jr (1996) Spatial patterns in phytoplankton biomass and pigment distributions in the Ross Sea. J Geophys Res 101:18467-18478

Dore JE, Karl DM (1996) Nitrification in the euphotic zone as a source for nitrite, nitrate, and nitrous oxide at Station ALOHA. Limnol Oceanogr 41:1610-1618

Ducklow HW, Carlson CA (1992) Oceanic bacterial production. In: Marshall KC (ed) Advances in microbial ecology. Plenum Press, New York, p 113-181

Ducklow HW, Kirchman DL, Quinby HL (1992) Bacterioplankton cell growth and macromolecular synthesis in seawater cultures during the North Atlantic spring phytoplankton bloom, May 1989. Microb Ecol 24:125-144

Dunbar RB, Leventer AR, Mucciarone DA (1998) Water column sediment fluxes in the Ross Sea, Antarctica (I): atmospheric and sea ice forcing. J Geophys Res (in press)

Eppley RW (1967) An incubation method for estimating the carbon content of phytoplankton in natural samples. Limnol Oceanogr 5:74-82

Eppley RW (1972) Temperature and phytoplankton growth in the sea. Fish Bull US 7:1063-1085

Goldman JC, Hansell DA, Dennett MR (1992) Chemical characterization of three large oceanic diatoms: potential impact on water column chemistry. Mar Ecol Prog Ser 88: $257-270$

Guillard RRL, Hellebust JA (1971) Growth and the production of extracellular substances by two strains of Phaeocystis pouchetii. J Phycol 7:330-338

Hobbie JE, Daley RJ, Jasper S (1977) Use of Nuclepore filters for counting bacteria by fluorescence microscopy. Appl Environ Microbiol 33:1225-1228

Hobson LA, Morris WJ, Pirquet KT (1976) Theoretical and experimental analysis of the ${ }^{14} \mathrm{C}$ technique and its use in studies of primary production. J Fish Res Board Can 33: $1715-1721$

Hu S, Smith WO Jr (1998) The effects of irradiance on nitrate uptake and dissolved organic nitrogen release by phytoplankton in the Ross Sea. Cont Shelf Res (in press)

Karl DM (1993) Microbial processes in the Southern Oceans In: Friedeman I (ed) Antarctic microbiology. Wiley-Liss New York, p 1-63

Kirk JTO (1994) Light and photosynthesis in aquatic ecosystems. Cambridge University Press, Cambridge

Lancelot C, Keller MD, Rousseau V, Smith WO Jr, Mathot S (1998) Auto-ecology of the haptophyte Phaeocystis sp. In
Anderson D, Hallegraeff G, Cembella A (eds) The physiological ecology of harmful algal blooms. NATO ASI Series Vol G41. Springer-Verlag, Heidelberg, p 211-224

Lancelot C, Mathot S (1985) Biochemical fractionation of primary production by phytoplankton in Belgian coastal waters during short-and long-term incubations with ${ }^{14} \mathrm{C}$ bicarbonate. II. Phaeocystis pouchetil colonial population Mar Biol 86:227-232

Lancelot C, Mathot S (1987) Dynamics of a Phaeocystisdominated spring bloom in Belgian coastal waters. I. Phytoplanktonic activities and related parameters. Mar Ecol Prog Ser 37:239-248

Lancelot C, Mathot S, Owens NJP (1986) Modeling protein synthesis, a step to an accurate estimate of net primary production: Phaeocystis pouchetii colonies in Belgian coastal waters. Mar Ecol Prog Ser 32:193-202

Lochte K, Bjorsnsen PK, Giesenhagen H, Weber A (1997) Bacterial standing stock and production and their relation to phytoplankton in the Southern Ocean. Deep Sea Res II $44: 321-340$

Martin JH, Fitzwater SE, Gordon RM (1990) Iron deficiency limits phytoplankton growth in Antarctic waters. Global Biogeochem Cycles 4:5-12

Osinga $R$, de Vries KA, Lewis WE, van Raaphorsl W, Dijkhuizen L, van Duyl FC (1997) Aerobic degradation of phytoplankton debris dominated by Phaeocystis sp. in different physiological stages of growth. Aquat Microb Ecol 12:11-19

Pakulski JD, Coffin RB, Kelley CA, Holder SL, Downer R, Aas P, Lyons MM, Jeffrey WH (1996) Iron stimulation of Antarctic bacteria. Nature 383:133-134

Peltzer ET, Hayward NA (1996) Spatial and temporal variability of total organic carbon along $140^{\circ} \mathrm{W}$ in the equatorial Pacifir Orean in 1992 Deen Sea Res II 43:11.55-1180

Prézelin BB (1981) Light reactions in photosynthesis. In: Platt $\mathrm{T}$ (ed) Physiological bases of phytoplankton ecology. Can Bull Fish Aquat Sci 210:1-43

Putt M. Miceli G, Stoecker DK (1994) Association of bacteria with Phaeocystis sp. in McMurdo Sound, Antarctica. Mar Ecol Prog Ser 105:179-189

Sakshaug E, Holm-Hansen O (1986) Photoadaptation in Antarctic phytoplankton: variations in growth rate, chemical composition and $\mathrm{P}$ versus I curves. J Plankton Res 8: $459-473$

Sambrotto R, Savidge G, Robinson C, Boyd P, Takahashi T, Karl DM, Langdon C, Chipman D, Marra J, Codispoti L (1993) Elevated consumption of carbon relative to nitrogen in the surface ocean. Nature 363:248-250

Sedwick PN, DiTullio GR (1997) Regulation of algal blooms in Antarctic shelf waters by the release of iron from melting sea ice. Geophys Res Lett 24:2515-2518

Sieburth JM (1960) Acry]ic acid, an 'antibiotic' principle in Phaeocystis blooms in Antarctic waters. Science 132: 676-677

Slezak DM. Puskaric S, Herndl GJ (1994) Potential role of acrylic acid in bacterioplankton communities in the sea. Mar Ecol Prog Ser 105:191-197

Smith DC, Azam F (1992) A simple, economical method for measuring bacterial protein synthesis in seawater using ${ }^{3} \mathrm{H}$-leucine Mar Microb Food Webs 6:107-114

Smith DC, Steward GF, Long RA, Azam F (1995) Bacterial mediation of carbon fluxes during a diatom bloom in a mesocosm. Deep Sea Res ll 42:75-97

Smith WO Jr, Dunbar RB (1998) The relationship between new production and vertical flux on the Ross Sea continental shelf. J Mar Syst (in press)

Smith WO Jr, Gordon LI (1997) Hyperproductivity of the Ross 
Sea (Antarctica) polynya during austral spring. Geophys Res Lett 24:233-236

Smith WO Jr, Nelson DM (1985) Phytoplankton bloom produced by a receding ice edge in the Ross Sea: spatial coherence with the density field. Science 227:163-165

Smith WO Jr, Nelson DM, DiTullio GR, Leventer AR (1996) Temporal ard spatial patterns in the Ross Sea: phytoplankton biomass, elemental composition productivity and growth rates. J Geophys Res 101:18455-18466

Sullivan CW, Arrigo KR, McClain CR, Comiso JC, Firestone J (1993) Distributions of phytoplankton blooms in the Southern Ocean. Science 262:1832-1837

Editorial responsibility: Jed Fuhrman (Contributing Editor), Los Angeles, California, USA
Terry KL, Hirata J, Laws EA (1983) Light-limited growth of two strains of the manne diatom Phaeodactylum tricornutum Bohlin: chemical composition, carbon partitioning and the diel periodicity of physiological processes. J Exp Mar Bı.ol Ecol 68:209-227

van Rijssel M, Hamm E.E, Gieskes WC (1997) Phaeocystis globosa (Prymnesiophyceae) colonies: hollow structures buılt with small amounts of polysaccharides. Eur J Phycol 32: 185- 192

Wassmann P. Vernet M, Mitchell BG, Rey F (1990) Mass sedimentation of Phaeocystis pouchetii in the Barents Sea. Mar Ecol Prog Ser 66:183-195

Submitted: October 4, 1997; Accepted: May 13, 1998 Proofs received from author(s): June 25, 1998 